
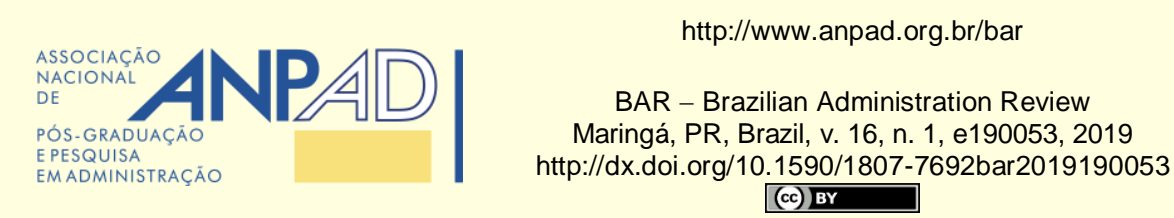

\title{
Editorial
}

\section{False Dichotomies (Part I): The Axiomatic Systems of Science and Religion, and Implications for Scholarly Publications}

\author{
Carlo Gabriel Porto Bellini \\ Editor-in-chief \\ Universidade Federal da Paraíba, João Pessoa, PB, Brazil
}

This is the first of my essays about certain false dichotomies that populate people's minds and have an enormous impact on how researchers conceive their activities, as well as on how reviewers and editors do their jobs. Given the abbreviated form in which I present the issues here, I call these pieces teasing essays, as they merely introduce the issues in order to motivate reflection and reply.

This first essay deals with the generally heated, long dispute between the advocates of two philosophical branches ${ }^{1}$ : that of pure science, and the more orthodox views of religion ${ }^{2}$. The dispute has been dividing people among those who believe in experience-based, testable knowledge, and those who believe that certain phenomena are unreachable to human examination and understanding, and as such can be explained only by means of revelations. I though concur with views that the two groups can engage in profitable dialogue instead of in narratives of conflict (Pritchard, 2016) or "frank disagreement" (Whitehead, 1925), while I also return to the basics to accentuate that science and religion are alternative ways to frame reality and I have no solid reason to see one as superior to the other. Moreover, I argue that the two philosophical branches should not be in jeopardy if their assumptions (or hopes) are not fully confirmed in everyday experience. That is, it should be no problem for the science lover if certain things remain hidden to human understanding; after all, humans rely only on their five senses to collect data about the world (what probably imposes critical limits to perception) and on one data processing unit (the brain) that is known to operate under the constraints of bounded rationality (Simon, 1979). Similarly, it should be no problem for the faith apologist if science ends up explaining everything; after all, the critical issue in most religions is to find the path to happiness and eternal salvation regardless of there being intelligible reasons for it or not. On another line 
of thought, supporters of pure science sometimes seem to "pay no attention to the plank in their own eyes" (Matthew 7:3-5, Bible, New International Version) when contesting the churchgoer's beliefs in matters of faith (as if science had no matters of faith too), while some churchgoers inflict unnecessary delays to the development of humankind when opposing to science as a way to make life easier.

In this essay, I briefly show that science and religion are but alternatives to frame human understanding, and that neither is either doubtlessly correct or incorrect if we use some of their own criteria as the analytical tools. Consequently, scholarly publications (such as BAR) should be taken as one - but not the only - possible way to knowledge.

\section{Four analytical aspects of science and religion}

Science and religion are two philosophical avenues that share crossroads. First, both are axiomatic systems. Any scientific field rests on certain theoretical assumptions or axioms, while religion rests on certain matters of faith. Axioms, theoretical assumptions and matters of faith are conceptually equivalent. They refer to issues that are taken for granted to enable further reasoning and action. For instance, in operations management, we assume that best practices in process quality lead to higher levels of product/service quality and organizational performance - but there is no straightforward proof for such a causal path. On the side of religion, matters of faith include such things like the origin and the destiny of the world, immortality and fate of the soul, the nature of consciousness, and the moral quality of certain human actions. Therefore, the typical accusation of the enthusiasts of pure science that religious groups take certain issues for granted without critique is incoherent with the easy verification that any scientific field or research effort also rests on a particular set of assumptions that are simply taken for granted. Assumptions are typically derived from what the scientific community calls a fact, i.e., "something that has been tested or observed so many times that there is no longer a compelling reason to keep testing or looking for examples" (National Academy of Sciences, 1999, p. 28). That definition is clearly fragile, as there is no guarantee that future observations will not reveal different manifestations of the said fact. Indeed, according to Popper's (2002) falsifiability criterion, any claim should be structurally falsifiable to have potential scientific value; as such, a given fact of agreed-upon scientific value may not hold true in future observations, and theories based on it thus collapse. The argument against the solidity of scientific assumptions goes on so as to include other issues on how the assumptions are crafted, such as how the empirical and the symbolic systems in measurement theory are connected by the observer (Mari, 2000), the observer's levels of consciousness (or schizophrenia), and the measurement problem of quantum mechanics (Leggett, 2005). As a result, we all know that neutrality in science does not exist in many senses ${ }^{3}$.

Second, both science and religion are formed by smaller communities that espouse slightly different or even incompatible traditions and views of the world. On the side of science, for instance, positivists and phenomenologists, not to say the advocates of noetics (Foltz, 2013; Krader, 2010), would disagree in almost everything regarding the natural phenomena (the ontological view of whether reality exists per se or is subjectively created) and how knowledge is 
appropriated (the epistemological and methodological views of whether and how to "touch" that reality). As a result, they also disagree on the scope of implications of a research's findings findings are either generalizable or not. In its turn, religion is also characterized by competing views across and within the religious groups about more dogmatic issues (e.g., the existence and the nature of superior beings, or how individual human action is conducive to personal salvation or ruin) and on more ordinary issues (e.g., if certain actions adhere to the doctrine or not, or who is eligible to lead a community of believers). As a result, individuals will be living a sacred or damned life depending on the particular religious perspective.

Third, both science and religion claim to search for, and be the guardians of, truth. For mainstream scientists, truth is what reality is, i.e., the nature and the mechanics of phenomena as brought to our conscience by direct human experience and repetition of observations. In turn, religious people assume truth as revelations made by superior human beings (e.g., prophets) or superior beings (e.g., gods), or as personally meaningful discoveries of the self. Also, religion-based truth is generally represented by directions on how to think and behave in certain ways and avoid certain thoughts and behaviors, with the aim of guiding people to happiness and eternally peaceful life. In other words, it is "the contemplation of moral and aesthetic values" (Whitehead, 1925). Religious groups thus assign value to thoughts and behaviors, whereas scientists are concerned with merely describing them. However, the idea of truth and the positive effects that stem from knowing and protecting it are critical to both philosophical communities.

Finally, both in science and in religion revolutionary movements challenge the status quo with new ideas from time to time, or there is natural evolution in how things are conceived. In science, when a radically new idea is institutionalized, it is said that a paradigm shift occurred (Kuhn, 1962). In religion, leaders use traditional knowledge to explain contemporary facts, but they also take the opportunity to develop new doctrine when needed. In some cases, there is also room for radical changes in doctrine, such as when Christ introduced a number of new directions for exemplary conduct. Of course, in highly dogmatic religions, opportunities for new thinking are not abundant, and modifications in religious thought are often seen as a defeat, contrary to what happens - enthusiasm - when new insights emerge in science (Whitehead, 1925).

So, why is that science and religion seem to discredit each other so frequently and give rise to false beliefs (such as that only science produces reliable knowledge or that religion does not need science) if both seem to share a number of characteristics? To me, the answer comes from the perception that it would be paradoxical if both views of the world (i.e., their key principles) were simultaneously right. For the supporters of pure science, religion has historically tried to interfere in scientific advance (and continues to do so in religion-centered political systems), but as a result produced some widely known fiascos. The most famous one is probably the $17^{\text {th }}$ century's Galileo case, when the Roman Catholic Church interfered in the advancement of astronomy but was later impelled to retract (New Scientist, 1992). That was an example of unnecessary action by the Church, as it had no impact on the really important issues of faith ${ }^{4}$. On the other hand, science tries to convince us about its superiority, while, for instance, research reproducibility/replication has been home to embarrassing results (Baker, 2016; Munafò et al., 2017). 
The best conduct thus seems to be that of acknowledging the positive aspects of both science and religion towards human understanding and peaceful social life, as neither philosophical community is so far able to fully persuade the curious thinker about one's superiority over the other. The Templeton Prize (http://www.templetonprize.org/) is a good example of how to invite the two communities to talk. According to the stated purposes of that recognition, it "honors a living person who has made an exceptional contribution to affirming life's spiritual dimension". The most recent (2019) laureate is Dr. Marcelo Gleiser ${ }^{5}$, a professor of natural philosophy, physics and astronomy at Dartmouth College, Hanover, NH, USA, who has been "a prominent voice among scientists, past and present, who reject the notion that science alone can lead to ultimate truths about the nature of reality".

\section{Implications for scholarly publications}

The editorial process of any scholarly journal - BAR included - is marked by the presence of the four issues I mentioned before on the similarities of science and religion. Particularly in the administrative studies as part of the applied social sciences, there are (1) intrinsic issues of faith concerning how reviewers and editors assign value to and trust a research's reported findings, as it is virtually impossible to verify and reproduce them; there are (2) controversies and disputes between the scholarly communities that form the field (authors, reviewers and editors included), not only due to the highly heterogeneous topics of interest (such as marketing, management information systems, human resources management, finance, accounting, public administration, and organizational strategy), but especially due to the multiple ontological, epistemological and methodological traditions espoused by each community; there are (3) attempts to unveil "truth" at the individual or group level (depending on the rationale on particularization or generalization) regarding a theoretical and applied domain; and there are (4) attempts to advance the frontiers of scholarly knowledge and directions for the practice in organizations through either radical or incremental change on the state-of-the-art of the acknowledged (or negotiated) "truth".

We thus must expect that the articles in the current issue of BAR involve all four aspects. Authors, reviewers and editors are assumed to have worked diligently to offer the scholarly and professional communities with relevant and rigorous administrative knowledge, but notes of caution should be always in mind. The studies herein convey diverse topics and views in the field, while also representing the particular ability of the people involved to screen those topics and views among the many that were submitted and processed by the editorial team. We truly hope that the reader will enjoy this issue, while there is always room to discuss what "truly" means.

\section{Notes}

\footnotetext{
${ }^{1}$ Here, I am not concerned with more traditional classifications of philosophy, such as those involving the branches of metaphysics, epistemology, logic, axiology, ethics, and aesthetics.

${ }^{2}$ Here, I frame religion in more traditional terms instead of including all systems of faith. Otherwise, even science would be considered a type of religion. Indeed, the original writings on the epistemological stance of positivism (Burrell \& Morgan, 1979) declare it as the universal religion (Comte, 1852).
} 
${ }^{3}$ For additional views about neutrality in science, please see Stevenson (1989) and Weaver, Snow, Hesburg, and Baker (1961).

${ }^{4}$ However, during the retraction ceremony on October 31, 1992, Pope John Paul II (1992) warned that a "tragic reciprocal misunderstanding was interpreted as an intrinsic opposition between science and faith" (emphasis added in the translation).

${ }^{5}$ BAR readers will like to know that Dr. Gleiser was born and raised in Brazil, and lived there until completing his Master's studies.

\section{References}

Baker, M. (2016). 1,500 scientists lift the lid on reproducibility. Nature, 533(7604), $452-454$. http://www.dx.doi.org/10.1038/533452a

Burrell, G., \& Morgan, G. (1979). Sociological paradigms and organisational analysis. London, UK: Heinemann.

Comte, A. (1852). Catéchisme positiviste. Retrieved from http://classiques.uqac.ca/classiques/Comte_auguste/ catechisme_positiviste/catechisme_positiviste.pdf

Foltz, B. V. (2013). The noetics of nature. New York, NY: Fordham University Press.

Krader, L. (2010). Noetics: The science of thinking and knowing. New York, NY: Peter Lang.

Kuhn, T. S. (1962). The structure of scientific revolutions. Chicago, IL: University of Chicago.

Leggett, A. J. (2005). The quantum measurement problem. Science, 307(5711), 871-872. http://dx.doi.org/10.1126/science.1109541

Mari, L. (2000). Beyond the representational viewpoint: A new formalization of measurement. Measurement, 27(2), 71-84. https://doi.org/10.1016/s0263-2241(99)00055-x

Munafò, M. R., Nosek, B. A., Bishop, D. V. M., Button, K. S., Chambers, C. D., Percie-du-Sert, N., Simonsohn, U., Wagenmakers, E.-J., Ware. J. J., \& Ioannidis, J. P. A. (2017). A manifesto for reproducible science. Nature Human Behaviour, 1, article 0021. https://doi.org/10.1038/s41562-016-0021

National Academy of Sciences. (1999). Science and creationism: A view from the National Academy of Sciences. Washington, DC: National Academy Press. Retrieved from https://www.nap.edu/read/6024/chapter/7\#28

New Scientist. (1992, November 7). Vatican admits Galileo was right. New Scientist, 1846. Retrieved from https://www.newscientist.com/article/mg13618460-600-vatican-admits-galileo-was-right/

Pope John Paul II. (1992, October 31). Discorso di Giovanni Paolo II ai partecipanti ala sessione plenária dela pontificia academia dele scienze. Libreria Editrice Vaticana. Retrieved from http://w2.vatican.va/content/john-paulii/it/speeches/1992/october/documents/hf_jp-ii_spe_19921031_accademia-scienze.html

Popper, K. R. (2002). The logic of scientific discovery. London, UK: Routledge.

Pritchard, K. (2016). Religion and science can have a true dialogue. Nature, 537(7621), 451. http://www.dx.doi.org/10.1038/537451a

Simon, H. A. (1979). Rational decision making in business organizations. American Economic Review, 69(4), 493-513.

Stevenson, L. (1989). Is scientific research value-neutral? Inquiry, 32(2), 213-222. https://doi.org/10.1080/00201748908602188

Weaver, W., Snow, C. P., Hesburg, T. M., \& Baker, W. O. (1961). The moral un-neutrality of science. Science, 133(3448), 255-262. https://doi.org/10.1126/science.133.3448.255

Whitehead, A. N. (1925, August). Religion and science. The Atlantic. Retrieved from https://www.theatlantic.com/magazine/archive/1925/08/religion-and-science/304220/ 


\section{Author}

\section{Dr. Carlo Gabriel Porto Bellini}

Associate professor of information systems, Department of Management, Universidade Federal da Paraíba Campus Universitário I, Jardim Cidade Universitária, 58059-900, João Pessoa, PB, Brazil bar-eic@anpad.org.br

(iD https://orcid.org/0000-0001-5809-3172 